\title{
Biochemical and Ultrastructural Changes in A and B Cells of the Islets of Langerhans of Mice Infected with EMC Virus
}

\author{
F. Zaheer, S. L. Howell ${ }^{1}$, K. W. Taylor ${ }^{2}$, T. J. Coleman ${ }^{3}$, and D. R. Gamble ${ }^{3}$ \\ School of Biological Sciences, University of Sussex, Falmer, Brighton, and ${ }^{3}$ Area Public Health Laboratory, West Park Hospital, \\ Epsom, England
}

Summary. Infection of $\mathrm{DBA}_{2}$ mice with the $\mathrm{M}$ strain of EMC virus was used to study the effects of virusinduced diabetes on the $\mathrm{A}$ and $\mathrm{B}$ cells of the islets of Langerhans. A transient hypoglycaemia was seen in $48 \%$ of mice $2-3$ days after infection and probably resulted from increased serum insulin concentrations together with inhibition of glucagon secretion at that time. Islets from hypoglycaemic mice showed no significant alterations from control level in basal or fluoride-stimulated adenylate cyclase activity. Overall, $70 \%$ of infected mice became hyperglycaemic with a maximum incidence 6 days after infection. Hyperglycaemia was accompanied by a dramatic reduction in the total pancreatic insulin content and in insulin secretory responses to glucose and theophylline, while A-cell structure and function appeared relatively unaffected in diabetic animals. Basal adenylate cyclase activity was increased in hyperglycaemic mice at 7 days after infection, while fluoride-stimulated adenylate cyclase activity was normal throughout the course of infection. Ultrastructural alterations were observed in a small proportion of $\mathrm{B}$ cells from two days after infection and included abnormalities of mitochondrial structure and increased electron opacity of the cytoplasm of affected cells, which subsequently led to complete necrosis. The results suggest that EMC virus specifically affects the $B$ cells of the islets and that disturbances of A cell function may be secondary to B cell damage.

Present addresses:

1 Department of Biochemistry, Charing Cross Hospital Medical School, Fulham Palace Road, London W6 8RF, England

2 Department of Biochemistry, The University of Sydney, Sydney, N.S.W. 2006, Australia
Key words: Diabetes, EMC virus, $\mathrm{DBA}_{2}$ mice, islets of Langerhans, ultrastructure, insulin, glucagon.

Diabetes induced in mice by the $M$ strain of EMC virus and by Coxackie $\mathrm{B}_{4}$ virus has provided interesting experimental models which have been the subject of reviews by Craighead [5, 6] and by Notkins [14]. These viruses normally rapidly destroy the cells in which they replicate, and insulin deficiency in infected animals may be the result of viral multiplication in the insulin producing B cells $[2,3]$. However, the suggestion that EMC infection may trigger immunologically mediated islet cell damage [13] raises the possibility that islet cells may be functionally impaired rather than destroyed.

We have investigated some metabolic and ultrastructural changes in A and B cells of mice infected with EMC virus in order to study the nature of any functional impairment.

\section{Materials and Methods}

\section{Animals and Virus}

Eight to sixteen-week-old male $\mathrm{DBA}_{2}$ mice (Olac Ltd., Bicester, Oxon.) were inoculated intraperitoneally with $0.2 \mathrm{ml}$ of a suspension of the M strain of encephalomyocarditis virus (EMC) [3] containing $10^{2}$ suckling mouse $\mathrm{LD}_{50}$ per ml. Control mice received $0.2 \mathrm{ml}$ of $150 \mathrm{mmol} / \mathrm{l}$ saline containing penicillin $(200 \mathrm{U} / \mathrm{ml})$ and streptomycin $(100 \mathrm{U} / \mathrm{ml})$. Mice were given free access to pasteurised mouse chow (Charles River 4RF) and water. Mice were killed by cervical dislocation at $2,3,7,14$ or 21 days after inoculation. Blood glucose concentrations were determined on all animals. Those animals shown in Fig. 1 were used for serum insulin and 


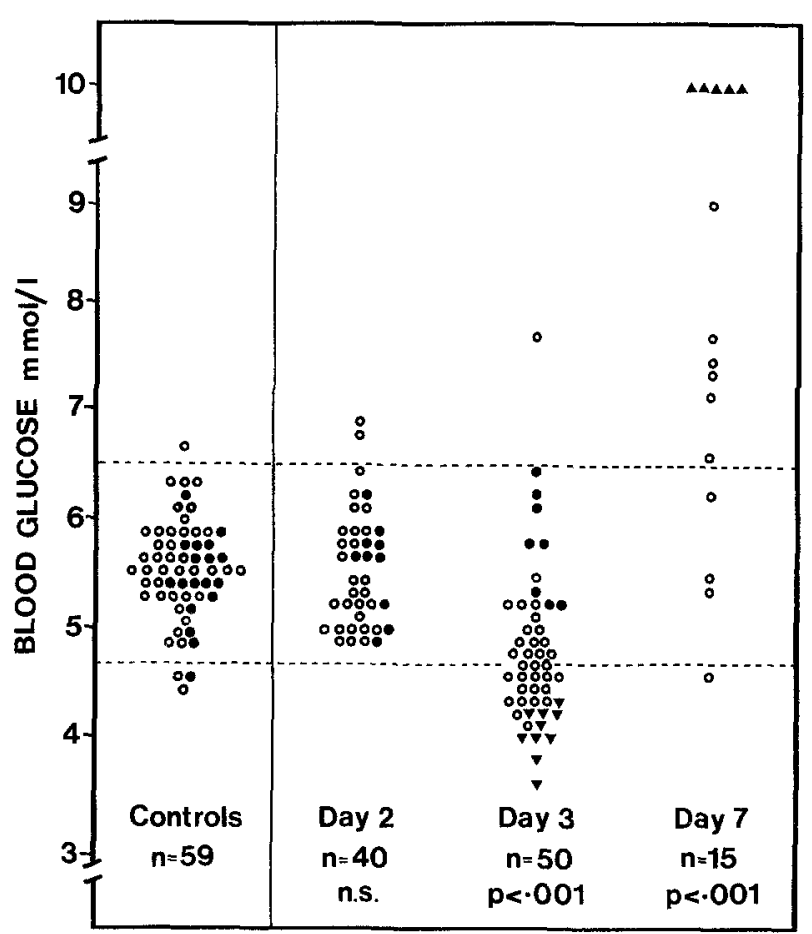

Fig. 1. Random blood glucose concentrations in mice after infection with EMC virus. Control group - comprised 20 uninfected mice. Blood glucose levels were determined in samples of at least 10 mice on days $0,2,3$ and 7 . Mean concentrations on these days were $5.7,5.3,5.8$ and $5.8 \mathrm{mmol} / 1$ respectively, which did not differ significantly. The 59 results shown are pooled results from all four days. Dotted horizontal lines show control mean \pm 2 S.D.'s. Test group - 80 mice were inoculated with EMC virus and samples as shown above, were tested for blood glucose concentration on days 2, 3 and 7. Serum insulin-solid symbols indicate mice selected on the basis of their blood glucose concentration, and killed for serum insulin determinations. $\boldsymbol{\nabla}$ hypoglycaemic, normoglycaemic, $\boldsymbol{\Delta}$ hyperglycaemic (offscale points were 20,18, 15, 15 and $10.7 \mathrm{mmol} / 1$ )

adenylate cyclase determinations. A similar group was used for estimation of insulin and glucagon content and glucagon secretion studies.

\section{Insulin and Glucagon}

Pancreases from normoglycaemic and hypoglycaemic animals at days 2-3, diabetic and non-diabetic infected animals at days 7 and 14 , and non-infected controls were studied. Yields of islets from control mice, and mice 2-3 days after infection, were in the range of $20-40$ islets per pancreas but yields from diabetic mice 7 or more days after infection were only $5-10$ per pancreas, presumably because islets damaged by infection were more fragile. For this reason, and because of the possibility of selective damage to the peripherally located A cells during isolation, estimations of insulin and glucagon content and glucagon secretion were performed on pancreas fragments.

The pancreas was removed immediately into bicarbonatebuffered saline $\mathrm{pH} 7.4$, cut into $3-6 \mathrm{mg}$ pieces with scissors and pre-incubated for $30 \mathrm{~min}$ at $37^{\circ} \mathrm{C}$ before testing secretory responses. In secretion tests single fragments were incubated at $37^{\circ} \mathrm{C}$ for $60 \mathrm{~min}$ in $0.6 \mathrm{ml}$ of medium containing $200 \mathrm{~K} . \mathrm{I} . \mathrm{U} . / \mathrm{ml}$ Trasylol (Bayer U.K. Ltd.), $1 \mathrm{mg} / \mathrm{ml}$ bovine serum albumin (Armour Pharmaceuticals, Eastbourne, England) and 5.5 or $20 \mathrm{mmol} / \mathrm{l}$ glucose in the presence of $5 \mathrm{mmol} / 1$ theophylline. After incubation the medium was removed and stored at $-20^{\circ} \mathrm{C}$ prior to assay of insulin and glucagon. The fragments were extracted with ethanol: $\mathrm{HCl}: \mathrm{H}_{2} \mathrm{O}(23: 0.45: 7$ by volume) by homogenisation in Tenbroek all-glass homogenisers; these extracts were diluted with $0.1 \mathrm{mmol} / 1$ phosphate buffer $\mathrm{pH} 7.4$ containing $1 \mathrm{mg} / \mathrm{ml}$ albumin and stored at $-20{ }^{\circ} \mathrm{C}$ for later immunoassay.

Insulin radioimmunoassay was performed according to Hales \& Randle [8] using human insulin standards (Wellcome Reagents Ltd., Beckenham, England). We have no evidence of major differences between cross reactivity of mouse or human insulin using this antiserum. Glucagon immunoassay utilised an antibody prepared by a polyvinylpyrrolidone procedure, using polyethylene glycol 6000 (B.D.H. Ltd., Poole, England) to separate antibodybound from free glucagon [9]. A 1/1000 dilution of the antiserum produced about $40 \%$ binding of total $\mathbf{I}^{125}$ glucagon. A displacement of $50 \%$ of the bound counts was observed after addition of $6 \mathrm{ng} / \mathrm{ml}$ glucagon. Glucagon was obtained from Eli Lilly \& Co., Indianapolis, Ind. $\mathrm{I}^{125}$ for labelling glucagon and insulin was obtained from the Radiochemical Centre, Amersham, Bucks.

\section{Electron Microscopy}

Islets were prepared by a collagenase digestion procedure [10]. Equal amounts of collagenase from two sources [Sigma Chemical Co. Ltd., London (150 U/mg) and Boehringer Ltd., Lewes, Sussex $(0.15 \mathrm{U} / \mathrm{mg})]$ were used for the digestion of the pancreas. Islets were fixed in $3 \%$ glutaraldehyde in $0.1 \mathrm{mmol} / 1$ phosphate buffer $\mathrm{pH} 7.4$, post-fixed in $2 \%$ osmium tetroxide in similar buffer, dehydrated and embedded by a standard procedure. Islets were stained with a saturated solution of uranyl acetate in $50 \%$ ethanol before examination in a JEOL $100 \mathrm{~S}$ electron microscope.

\section{Adenylate Cyclase Activity}

Islet homogenates were used to estimate the conversion of $\alpha^{32} \mathrm{P}$ ATP (Radiochemical Centre, Amersham, Bucks.) to cyclic AMP ${ }^{32}$ the products being separated on alumina columns which were eluted with $10 \mathrm{mmol} / 1$ tris- $\mathrm{HCl}, \mathrm{pH} 7.6$ [11].

\section{Glucose Estimations}

Blood glucose was measured by a glucose oxidase procedure using a commercially available kit (Boehringer Ltd., Lewes, Sussex).

\section{Calculation of Results}

Results are expressed as mean \pm SEM. Significance of differences are assessed using Student's t-test.

\section{Results}

Random blood glucose determinations were used to select groups of mice for further experiments. Results for uninfected mice and for mice tested 2, 3 and 7 days after infection are shown in Figure 1. The mean \pm SEM blood glucose concentration in control mice was $5.6 \pm 0.1 \mathrm{mmol} / 1$. A proportion of infected mice 
were hypoglycaemic on day 3 when the mean glucose concentration was $4.8 \pm 0.1 \mathrm{mmol} / 1$, and $24 / 50(48 \%)$ of the mice had blood glucose concentrations more than $2 \mathrm{SD}$ below the mean control value. Animals used for serum insulin determinations and adenylate cyclase determinations are indicated with closed symbols in Figure 1. The serum insulin concentrations are shown in Figure 2, from which it is clear that hypoglycaemic mice on day 3 had serum insulin values significantly higher than controls, while hyperglycaemic animals on day 7 had significantly reduced serum insulin levels. However, the insulin secretory responses of pancreatic fragments from hypoglycaemic animals 3 days after infection were not significantly different from normal. Thus, in 15 experiments using pancreatic fragments obtained from hypoglycaemic mice 3 days after infection, the mean \pm SEM insulin release rates in the presence of 5 and $20 \mathrm{mmol} / 1$ glucose were $0.49 \pm 0.16$ and $1.10 \pm$ $0.26 \mu \mathrm{g} / \mathrm{mg}$ wet weight $/ \mathrm{h}$ respectively, compared with $0.41 \pm 0.12$ and $0.94 \pm 0.20 \mu \mathrm{g} / \mathrm{mg}$ wet weight/ $\mathrm{h}$ respectively in 15 tests using uninfected mice. As noted previously [19] the ability of the B cells to respond to 5 or $20 \mathrm{mmol} / 1$ glucose or $20 \mathrm{mmol} / 1$ glucose $+5 \mathrm{mmol} / 1$ theophylline was severely impaired in pancreas fragments removed 7,14 and 21 days after infection.

\section{Insulin}

The insulin content of control mouse pancreas ranged from $50-80 \mu \mathrm{g} / \mathrm{mg}$ wet weight of pancreas, equivalent to a mean content of 1.54 units $/ \mathrm{g}$ pancreas. Some day-to-day variation in extractable insulin content was observed and for this reason control and virus-infected pancreas was extracted simultaneously in every experiment and the results expressed as percentages of the content of control fragments. The insulin content of pancreas fragments from mice killed 2-3 days after infection was reduced, but was not significantly different from controls, but by days 7 and 14 it had fallen to $13 \%$ and $36 \%$ respectively of control levels (Fig. $3 \mathrm{a}$ ). At 21 days after infection insulin content was $23 \%$ of the control level.

\section{Glucagon}

Glucagon secretion from pancreas fragments in response to $5 \mathrm{mmol} / 1$ glucose plus $5 \mathrm{mmol} / 1$ theophylline showed no significant differences between control or diabetic or normoglycaemic infected mice at days 7,14 or 21 (Fig. 4). However, in hypoglycaemic mice on day 2, basal rates of glucagon release in the presence of $5 \mathrm{mmol} / 1$ glucose alone were significantly reduced, although the response to glucose

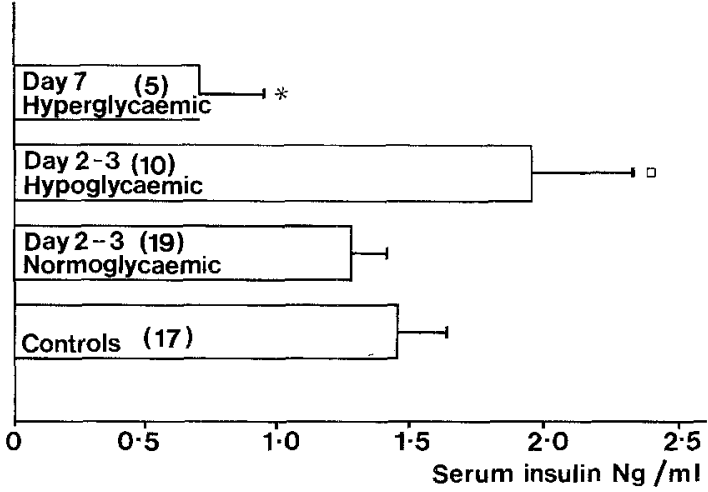

Fig. 2. Random serum insulin concentrations in mice after infection with EMC virus. Results shown are the mean \pm SEM of the number of observations shown in parentheses. *Indicates result significantly different from uninfected mouse controls. $(p<0.05)$; $\square$ indicates result significantly different from day $2-3$ normoglycaemic values $(\mathrm{p}<0.05)$
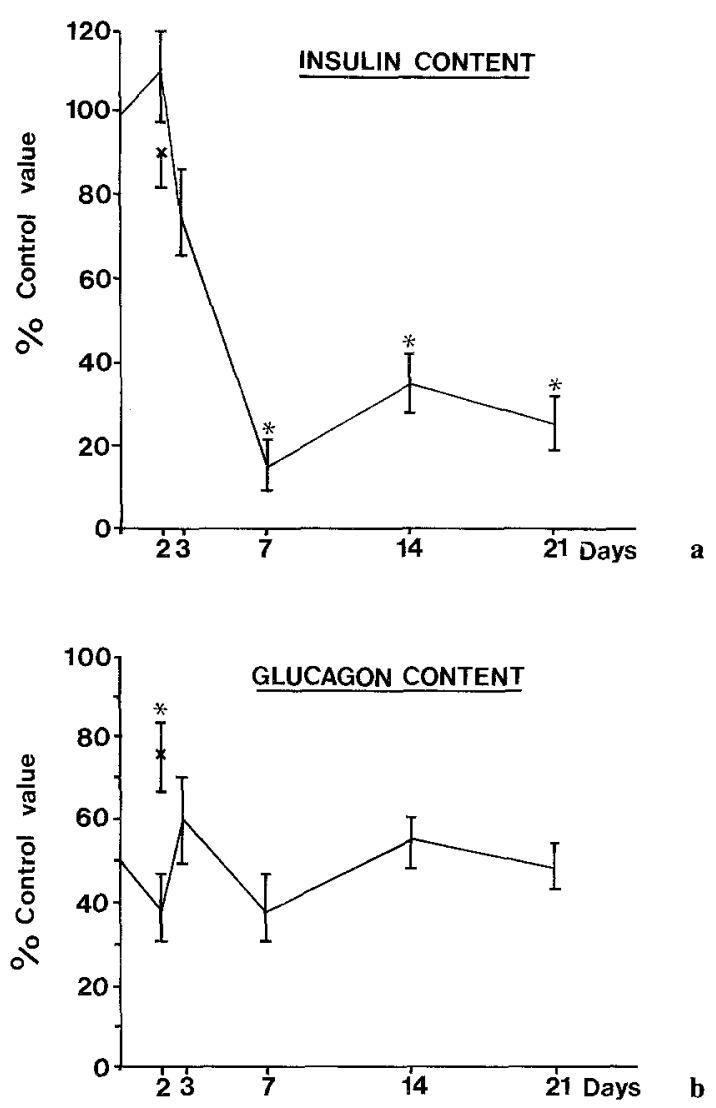

Fig. 3. Insulin (a) and glucagon (b) content of mouse pancreas 2-21 days after infection with EMC virus, expressed as mean \pm $\mathrm{SEM} \%$ of the control values for pancreas extracted on the same day. Day 2 results included on the graph are from normoglycaemic animals (see Fig. 1), results for the hypoglycaemic group at day 2 are indicated by $\mathrm{x}$ in each case. Values significantly different from control (uninfected mice) $\mathrm{p}<0.05$ are shown by an asterisk 
Table 1. Adenylate cyclase activity in homogenates of islets from normal or EMC-virus infected mice. Activities are shown as mean \pm SEM pmol cAMP formed/mg protein/min. Number of observations are shown in parentheses. "Indicates significant difference from control value $\mathrm{p}<0.05$

\begin{tabular}{lllll}
\hline & Control & $\begin{array}{l}\text { Day 2 } \\
\text { Normoglycaemic }\end{array}$ & $\begin{array}{l}\text { Day 2 } \\
\text { Hypoglycaemic }\end{array}$ & $\begin{array}{l}\text { Day } 7 \\
\text { Hyperglycaemic }\end{array}$ \\
\hline Basal activity: & $15.0 \pm 0.9(12)$ & $16.1 \pm 1.2(12)$ & $17.1 \pm 1.1(12)$ & $19.4 \pm 1.6 *(6)$ \\
Na Fluoride (10 mmol/l) stimulated activity: & $30.9 \pm 1.4(12)$ & $34.6 \pm 1.6(12)$ & $30.7 \pm 1.5(12)$ & $33.2 \pm 2.99(6)$ \\
\hline
\end{tabular}

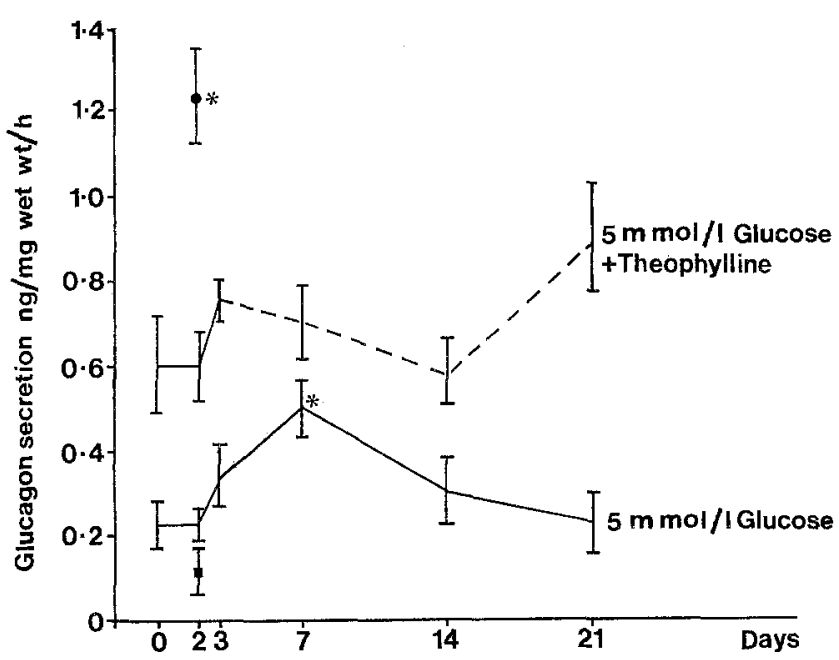

Fig. 4. Glucagon secretion from pancreatic fragments obtained from mice 2, 3, 7, 14 or 21 days after infection with EMC virus. 'Basal' rates of secretion in the presence of $5 \mathrm{mmol} / \mathrm{l}$ glucose and secretion in response to $5 \mathrm{mmol} / 1$ theophylline are shown. The points included on the graph for day 2 show values for normoglycaemic animals. Values for hypoglycaemic mice on day 2 are also indicated; $5 \mathrm{mmol} / 1$ glucose, $5 \mathrm{mmol} / 1$ glucose + theophylline. All values are mean \pm SEM of $6-8$ observations. *Indicates significant difference from uninfected control $(p<0.05)$

plus theophylline was significantly higher than that found in normoglycaemic animals on the same day (Fig. 4). Basal rates of glucagon release were increased 7 days after infection.

Pancreatic glucagon content showed little variation following infection, with the exception of hypoglycaemic animals at days $2-3$, which showed a significantly elevated glucagon content (Fig. 3 b).

\section{Adenylate Cyclase Activity}

Basal and fluoride stimulated adenylate cyclase activity of islets from control and infected animals at 2-3 days after infection were similar, regardless of the blood glucose concentration at that time (Table 1). However, diabetic mice at 7 days after infection showed a significantly raised basal activity of the enzyme.

\section{Ultrastructure of Islets from Infected Animals}

Our examination concentrated especially on days 2 and 3 when changes in cell structure were visible but before diabetes had developed. Throughout these studies it was clear that only a relatively small proportion of the $B$ cells was affected by the changes described, and it was frequently possible to observe apparently normal cells, adjacent to those in an early stage of viral attack and completely destroyed cells. In islets from animals sacrificed on the second day after infection increased electron opacity of both mitochondria and cytoplasm was seen. Abnormalities of mitochondrial form and structure were apparent, the cristae being very clearly evident (Fig. 5). The presumed sequel to this stage in the development of B cell necrosis is shown in Figure 6 in which almost complete necrosis of the affected cell is seen. At subsequent stages cell debris can be seen being engulfed by macrophages. In no cases were signs of comparable degeneration of A cells observed. Virus particles were not seen in the cytoplasm of either cell type. The existence at 3 days onwards of large numbers of intact granules even in severely damaged cells may account for the absence of a fall in insulin content of the pancreas until such time as destruction of granules and their contents by macrophages occurs, although we have not yet undertaken a morphometric study which would substantiate this hypothesis. Nor have we completed detailed studies of somatostatin and pancreatic polypeptide secreting cells in virus infected pancreas.

\section{Discussion}

The results of this study suggest that this strain of EMC virus does show a considerable degree of specificity for the pancreatic $\mathrm{B}$ cells of $\mathrm{DBA}_{2}$ mice, in contrast to the earlier findings of Petersen et al. [15]. While A cell function remains relatively unaffected after infection some alterations do occur, in particular a depressed basal release but enhanced secretion in response to theophylline stimulation in hypogly- 


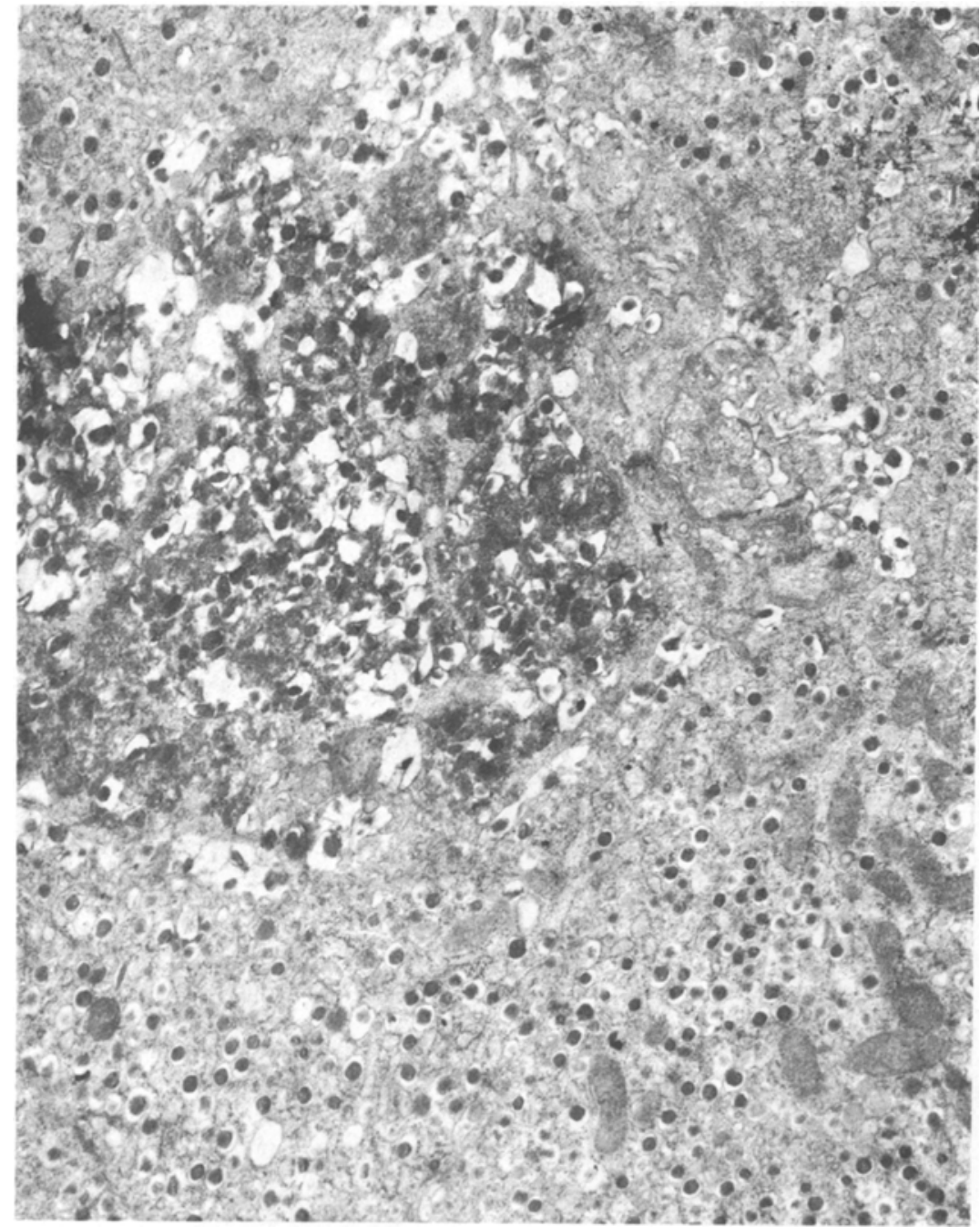

Fig. 5. B cells from a mouse islet 3 days after infection with EMC virus. Features are the increased electron opacity of the cytoplasm, large number of granules and swelling and abnormal appearance of the mitochondria. The surrounding cells which remain appear normal. $\times 18,000$ approx caemic mice at day 2, and an increased basal rate of release at day 7 . The explanation for these alterations in regulation of glucagon secretion is uncertain. They do not appear to reflect $A$ cell destruction since, with the exception of the hypoglycaemic animals at days $2-3$, pancreatic glucagon content remains unaltered throughout the 21 days after infection.

It was of particular interest to study the changes occurring early in the course of infection before the development of overt diabetes since this might provide some clue as to the events leading to $B$ cell destruction, and understanding of the origins of the transitory period of hypoglycaemia observed in some animals 2-3 days after infection. From our results it seems likely that the hypoglycaemia has at least two separate but possibly related causes. Firstly, serum insulin levels are increased. Secondly, there appears to be an inhibition of basal glucagon release which was observed in vitro and which was reflected in a reciprocal increase in glucagon content of the pancreas fragments. An explanation of the observed inhibition of glucagon release in vitro and increased serum insulin may be that viral damage to the B cells is responsible for the enhanced insulin release which causes the observed hypoglycaemia. The increased insulin concentration may inhibit glucagon release by a direct effect on the A cells [15] or indirectly by allowing increased entry of glucose into the A cells despite the presence of a low blood glucose [13]. Thus the situation in hypoglycaemic animals at days 2-3 may be similar to that seen in insulinoma where glucagon secretion is low despite the presence of hypoglycaemia and raised serum insulin levels [17].

In these experiments increased insulin release from pancreatic fragments from hypoglycaemic mice could not be demonstrated, and although the insulin content of the pancreas was reduced by $25 \%$ this reduction was not statistically significant. The reason 


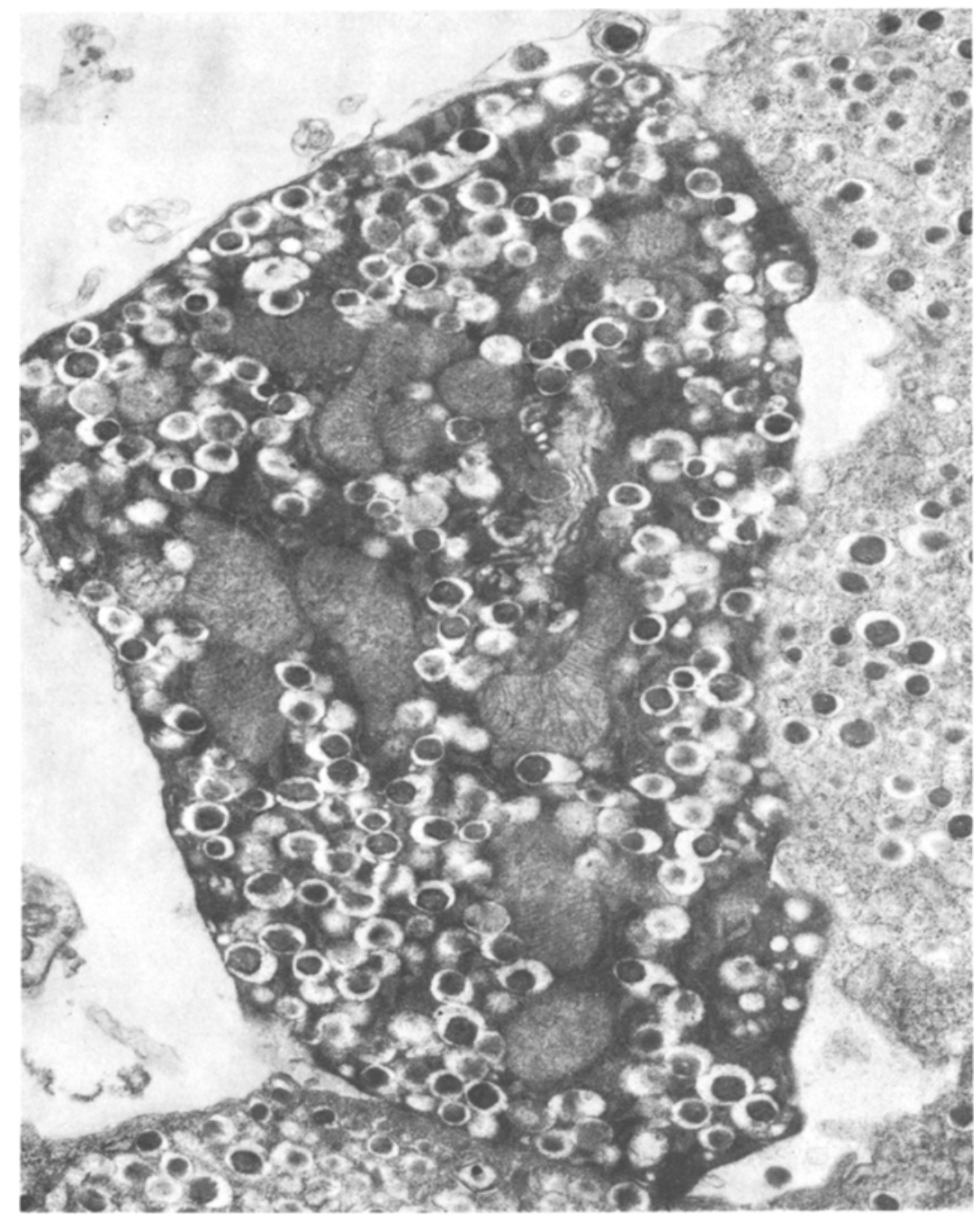

Fig. 6. $B$ cells of mouse islets 3 days after EMC virus infection. The cytoplasm of the affected cell at an advanced stage of disorganisation, presumably just before its final lysis. $\times 9,500$ approx for the increased serum insulin is therefore uncertain but leakage from damaged cells remains a clear possibility. This may be difficult to demonstrate in vitro because only a small proportion of $\mathrm{B}$ cells were affected. An alternative explanation might be that secretion of insulin from unaffected cells is increased in these conditions but this would seem unlikely in hypoglycaemic mice.

Adenylate cyclase, an enzyme located in B cell plasma membranes, was investigated in view of the possibility that a major disturbance of plasma membrane function might be an important stage in the onset of viral attack on B cells. However, there was no evidence in the present study for any alteration in the activity of this enzyme during the first 2-3 days after infection. Diabetic mice 7 days after infection showed a significantly raised activity and this might be due to long-term activation of basal activity by glucose as previously reported [12].
Ultrastructural studies similarly concentrated on the early days after infection since later stages of B cell necrosis have already been studied by previous authors $[4,18]$. It seems likely that the islet isolation procedure would select islets least damaged by infection and our ultrastructural findings may not reflect the pattern of cell damage in vivo. However, our observations of selective damage of B cells in isolated islets are consistent with the biochemical findings. The increased electron opacity of affected cells and alterations of mitochondrial structure are at least consistent with a viral attack; comparable changes in mitochondrial structure have been observed in other organs of animals which had been infected with EMC virus [1], although other features noted by these authors were not observed in our study.

Overall our results suggest that islet cell damage during EMC virus infection is specific for the B cell, and that the observed disturbance of glucagon secre- 
tion could well have been secondary to B cell damage. Although insulin secretion in response to glucose stimulation was reduced, it seems unlikely that a specific impairment of the secretory process was responsible for the hypoinsulinaemia, since the insulin content of the pancreatic fragments was grossly reduced. Moreover, the clear evidence of B cell destruction provided by the ultrastructural studies suggests that the most likely explanation for the insulin deficiency is simply a reduction in the B cell complement.

Acknowledgements. Financial contributions towards the cost of this work from the Medical Research Council (to DRG) and the British Diabetic Association are gratefully acknowledged. We thank Mrs. M. Hawkins, Mrs. M. Hodge and Mrs. M. Tyhurst for excellent assistance.

\section{References}

1. Burch, G. E., Harb, J. M.: Characteristic ultrastructural changes in organs of newborn mice infected with EMC virus. Proc. Soc. Exp. Biol. Med. 146, 1076-1086 (1974)

2. Coleman, T.J., Gamble, D. R., Taylor, K. W.: Diabetes in mice after Coxsackie B4 infections. Br. Med. J. 1973 III, 25-27

3. Craighead, J. E., McLane, M. F.: Diabetes mellitus: induction in mice by encephelomyocarditis virus. Science 162, 913-914 (1968)

4. Craighead, J. E., Kanich, R. E., Kessler, J. B.: Lesions of the islets of Langerhans in encephalomyocarditis virus-infected mice with diabetes mellitus-like disease. Am. J. Pathol. 74, 287-294 (1974)

5. Craighead, J. E.: The role of viruses in the pathogenesis of pancreatic disease and diabetes mellitus. Prog. Med. Virol. 19, 162-214 (1975)

6. Craighead, J. E.: Virus induced insulitis in experimental animal models. Acta Endocrinol. [Suppl. 205] (Kbh.) 83, 123-126 (1976)

7. Gey, G. O., Gey, M. K.: Maintenance of human normal cells and tumour cells in tissue culture. Am. J. Cancer 27, 45-76 (1936)

8. Hales, C. N., Randle, P. J.: Immunoassay of insulin with insulin-antibody precipitate. Biochem. J. 88, 137-146 (1963)
9. Henquin, J.C., Malvaux, P., Lambert, A.E.: Glucagon immunoassay using polyethylene glycol to precipitate antibodybound hormone. Diabetologia 10, 61-68 (1974)

10. Howell, S. L., Taylor, K. W.: Effect of glucose concentration on incorporation of $\left[{ }^{3} \mathrm{H}\right]$ leucine into insulin in isolated rabbit islets of Langerhans. Biochim. Biophys. Acta 130, 519-521 (1966)

11. Howell, S. L., Montague, W.: Adenylate cyclase activity in isolated rat islets of Langerhans: effects of agents which alter rates of insulin secretion. Biochim. Biophys. Acta 320, 44-52 (1973)

12. Howell, S. L., Green, I. C., Montague, W.: A possible role of adenylate cyclase in the long-term dietary regulation of insulin secretion from rat islets of Langerhans. Biochem. J. 136, 343-349 (1973)

13. Jansen, F. K., Müntefering, H., Schmidt, W. A. K.: Virus induced diabetes and the immune system. I. Suggestion that appearance of diabetes depends on immune reactions. Diabetologia 13, 545-549 (1977)

14. Notkins, A. L.: Virus induced diabetes mellitus. Arch. Virol. 54, 1-17 (1977)

15. Petersen, K. G., Heilmeyer, P., Kemp, L.: Synthesis of proinsulin and large glucagon immunoreactivity in isolated Langerhans islets from EMC-virus infected mice. Diabetologia 11, 21-26 (1975)

16. Samols, E., Tyler, J., Miahle, P.: Suppression of pancreatic glucagon release by the hypoglycaemic sulphonylureas. Lancet 1969 I, $174-176$

17. Unger, R.H., Orci, L.: Physiology and pathophysiology of glucagon. Physiol. Rev. 56, 778-826 (1976)

18. Wellman, K.F., Amsterdam, D., Brancato, P., Volk, B. W.: Fine structure of pancreatic islets of mice infected with the $M$ variant of the encephalomyocarditis virus. Diabetologia $\mathbf{8}$, 349-357 (1972)

19. Zaheer, F., Howell, S. L., Taylor, K. W., Gamble, D. R.: Pancreatic insulin and glucagon content and secretion after infection of mice with EMC virus. Biochem. Soc. Trans. 5, 1058-1060 (1977)

Received: August 9, 1978,

and in revised form: March 23, 1979

\section{S. L. Howell}

Department of Biochemistry

Charing Cross Hospital Medical School

Fulham Palace Road

Hammersmith

London W6 8RF, England

Since this manuscript was submitted a paper has appeared which describes changes in relative volumes of A, B, D and PP cells in mice following EMC virus infection studied by immunofluorescence microscopy (Stefan et al.: Diabetologia 15, 395-401, 1978). Although these authors did find some changes in the volumes of $\mathrm{A}_{1}, \mathrm{D}$ and PP cells they were relatively small compared with the marked reduction in the volume of B cells. 